Article

\title{
Twitter Analysis of Global Communication in the Field of Sustainability
}

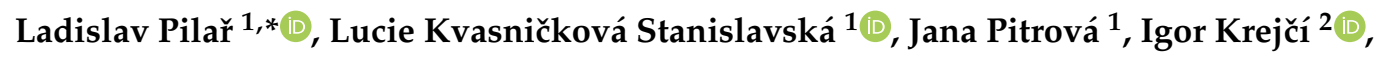 \\ Ivana Tichá ${ }^{1}$ and Martina Chalupová ${ }^{1}$
}

1 Department of Management, Faculty of Economics and Management, Czech University of Life Sciences Prague, 16521 Prague, Czech Republic; kvasnickova@pef.czu.cz (L.K.S.); pitrovaj@pef.czu.cz (J.P.); ticha@pef.czu.cz (I.T.); chalupovam@pef.czu.cz (M.C.)

2 Department of Systems Engineering, Faculty of Economics and Management, Czech University of Life Sciences Prague, 16521 Prague, Czech Republic; krejcii@pef.czu.cz

* Correspondence: pilarl@pef.czu.cz

Received: 28 October 2019; Accepted: 4 December 2019; Published: 6 December 2019

\begin{abstract}
The increasing popularity of social media worldwide provides us with an opportunity to understand social, cultural, and environmental issues about people's perception of sustainability. The article aims at identifying the main topics of communication related to hashtag \# sustainability based on a communication analysis on the Twitter network. We investigated the perception of sustainability using data from 414,926 Twitter interactions by 223,476 users worldwide. The data were recorded between April 17, 2018 and July 12, 2019. We identified Innovation, Environment, Climate Change, Corporate Social Responsibility, Technology, and Energy as key hashtags in the field of sustainability. In conjunction with this, we identified the six following communities: (1) Environmental Sustainability, (2) Sustainability Awareness, (3) Renewable Energy and Climate Change, (4) Innovative Technology, (5) Green Architecture, and (6) Food Sustainability. The usage of these communities is applicable in marketing communication as well as in the Corporate Social Responsibility activities of the given companies. The results of the analysis give the organizations a possible direction for their sustainable business model improvement via the contribution of society's voice.
\end{abstract}

Keywords: sustainability; environmental sustainability; innovation; environment; climate change; corporate social responsibility; food innovation; green architecture

\section{Introduction}

As mankind's efforts to attain sustainable development increase, each year sees more research studies into this topic [1]. Sustainability has received more attention in the past few decades, and has, increasingly, been incorporated into the agendas of policymakers and institutions, as well as into the strategies of companies. The term "sustainability" is often rather vaguely used to describe everything that is good and desirable [2]. With mounting evidence of environmental risks such as climate change, the rate of biodiversity loss, and the global nitrogen cycle, comes an increase in the public's attention to sustainability. These environmental issues have been investigated since the 1960s, and the core question has primarily been whether the present prosperity can be maintained [3,4]. This could explain why the concept of sustainability used to be frequently considered in the context of environmental issues. Even though its social and economic dimensions have been considered at the same time [5], they tended to be viewed as less significant issues [6]. The global attention to sustainability began after the Stockholm Conference on the Human Environment in 1972 and the report Limits to Growth, in which the tensions between the environment and development were first acknowledged. These were followed by the 1980s' World Conservation Strategy of the International Union for the Conservation 
of Nature, which argues for a sustainable development that uses species, ecosystems, and resources, as well as for the use of conservation as a means of development [7].

In 1982, the World Commission on Environment and Development was initiated by the General Assembly of the United Nations. Its 1987 report, Our Common Future (aka the Brundland Report), marked a major step forward in global or 'one-world' thinking [8]. The report defined sustainable development as "development that meets the needs of the present without compromising the ability of future generations to meet their own needs" [8] (p. 26). This definition has been used by research in the fields of renewable sources [9-12], mechanical engineering [13,14], agriculture [15], knowledge and innovation management [16-20], the environment [21-23], logistics [24], sustainable development [25-29], and innovations in the construction industry [30]. Sustainability is therefore a broad concept that has been used in a wide variety of fields, from human sciences to highly technological fields.

Another step forward in the global recognition of the importance of sustainability was the United Nations Conference on Environment and Development (UNCED) in Rio de Janeiro in 1992 (commonly known as the 'Earth Summit') and its declaration of principles. It consists of Agenda 21, which is a detailed account of desired actions, international agreements on climate change and biodiversity, and a statement of principles on forests. What is remarkably relevant to the extensive dissemination of the term 'sustainability', and its common understanding, is the triple bottom line - the three pillars of the concept: people, profit and planet [31]. During the United Nations (UN) Millennium Summit in 2000, 147 states gathered and adopted the Millennium Development Goals (MDGs). The Summit predominantly addressed various dimensions of poverty, including hunger, disease, income, poverty, and exclusion and lack of adequate shelter, while simultaneously focusing on education, gender equality, and environmental issues, with quantitative targets set for 2015 [6]. After the World Summit on Sustainable Development in South Africa in 2002, sustainability spread rapidly as a movement, becoming crucial to the missions of various stakeholders, referring to the triple bottom line as systematically and continuously intertwined environmental, economic, and social spheres [7].

In 2015, the United Nations' 2030 Agenda for Sustainable Development set 17 interconnected Sustainable Development Goals (SDGs) and 169 associated targets that aimed to shape global development policy and actions (UNGA, 2015). These SDGs not only focused on persistent needs, such as education, health, poverty eradication, and a clean environment, but also set forward 'softer' needs, such as more peaceful and inclusive societies [32]. It is worth noting that only several targets refer to ICT, but the Agenda fundamentally recognizes the potential of global interconnectedness and knowledge societies [33], pointing out that with the rapid development of ICT, including social media, SDGs should be dynamic and flexible in responding to unpredictable changes.

\section{Value of Social Media Analysis}

Monitoring and identifying current technological trends "is crucial for government policy, research and development, strategic planning, social investment, and enterprise practices" [34] (p. 687), such as decision-making about the technology portfolio or investment incentives [35]. Over 2.82 billion people use social media [36], and analyzing the data derived from social media offers insights into worldwide communication. Indeed, interest groups are no longer passive message recipients, but actively co-create communication in individual social networks [37]. They may be active on standard social networks such as Twitter and Instagram or on discussion forums [38], or they may insert their comments into articles in on-line news sites [39]. Such activities in social media take the form of expressing one's opinions, describing experiences, informing others of research results, or broadcasting realized or planned activities [40-42]. This constitutes the main reason to pay attention to an analysis of the communicated content. Content analysis allows us to understand key aspects of a discussion, identify the key topic, potentially engage interest groups, and encourage a communication partner to become a part of a conversation [43]. One cannot only acquire data containing messages from a communication. It is necessary to employ methods from social media analysis and social network 
theory to understand the conversation [40]. In the area of social network analysis, it is possible to use the content analysis of the text and the analysis of the attachment, photo or video [44]. So far, photo and video analysis is only a marginal area of social network analysis, which is gaining in importance due to rapidly growing content sharing on Instagram, which is mainly specialized in images [45]. The aim of image analysis is primarily to provide further information on the context of the report, such as the location (for example a farmers' market or a railway station) or fashion trends [45]. The text analysis is then focused on identifying keywords, using social networking techniques based on frequency distributions [46], or eigenvector and betweenness centrality [41,42]. Another area of the text analysis is sentiment analysis, which focuses on identifying the users' feelings [47]. The current limitation of this analysis is the categorization of data, which makes it very difficult to identify irony and sarcasm. That is the reason why the current research focuses on the prospective use of artificial intelligence in this field [48]. An alternative way to achieve the knowledge-from-text part of social networking data is analyzing the content of a communication by means of a hashtag analysis [41,42], a method that focuses exclusively on the hashtag type of metadata tag used on social networks to establish communities and to represent users voices [49], which was the focus of the present study. Namely, we adopted a communication analysis of the Twitter network to identify the main topics of communication related to the hashtag \#sustainability.

\section{Materials and Methods}

The Netlytic Software [50] was used to acquire tweets (messages) from Twitter social network communication. The data were recorded between April 17, 2018 and July 12, 2019. The software captured messages that used the hashtag \#sustainability. A total of 414,926 Twitter messages written by 223,476 unique users worldwide were recorded during this period. The data analysis is based on the Knowledge Discovery in Databases (KDD) process [51] and is modified to the social media data analysis requirements with a focus on hashtags (see Figure 1). The process consists of 4 activities:

(1) Content filtration - As the analysis only focused on hashtags, all words that were not preceded by the symbol \# were removed. This led to a dataset that consisted purely of hashtags (i.e., words beginning with the symbol \#).

(2) Content transformation - Subsequently, all letters were transformed to lower-case letters to prevent potential duplicities (e.g., the software might consider \#Environment and \#environment as two different hashtags). A further correction was made to break up strings of connected hashtags, e.g., "\#environment\#energy" was converted to "\#environment \#energy". The data set was imported into Gephi 0.9.2. Thus, a network was created containing 44,219 nodes (hashtags) that were interconnected by 423,276 edges (see Figure 2). The data were used for the basic network characteristics (see Table 1) and the frequency value (see Table 2).

(3) Hashtag reduction - To detect communities is necessary to process a hashtag reduction to remove micro-communities. A large number of communities is caused by an extensive number of hashtags that contained local hashtags and hashtags created by the users themselves.

(4) Data Mining - The following methods were used to describe the network.

Table 1. Basic network characteristics before and after the hashtag reduction.

\begin{tabular}{ccc}
\hline & Unreduced Network & Reduced Network ${ }^{* *}$ \\
\hline Number of Hashtags & 44,219 & 1927 \\
Number of Edges & 423,276 & 85,375 \\
Average Degree & 19.145 & 88.609 \\
Modularity & 0.271 & 0.188 \\
Number of Communities & 1027 & 6 \\
\hline
\end{tabular}

Note: ${ }^{* *}$ Hashtags that occurred fewer than 50 times in the dataset were removed from the network. 


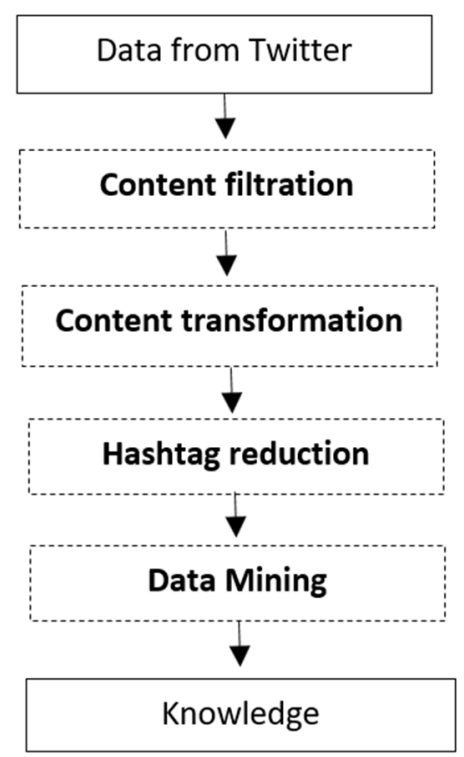

Figure 1. The process of data analysis.

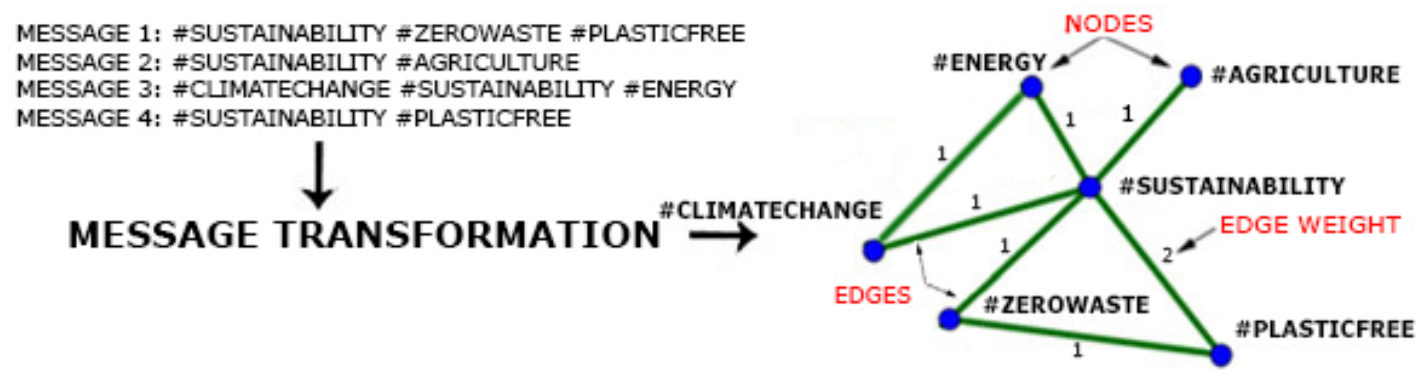

Figure 2. Transformation from Twitter messages to network.

\subsection{Eigenvector Centrality}

Eigenvector centrality is an extension of the degree centrality and measures the influence of hashtags in a network. The value is calculated based on the premise that connections to hashtags with high values (hashtags with a high degree centrality) have a greater influence than links with hashtags of similar or lower values. A high eigenvector centrality score means that a hashtag is connected to many hashtags with a high value and is calculated as follows:

$$
x_{v}=\frac{1}{\lambda} \sum_{t \in M(v)} x_{t}=\frac{1}{\lambda} \sum_{t \in G} a_{v, t} x_{t}
$$

where $\mathrm{M}(v)$ denotes a set of adjacent nodes and $\lambda$ is the largest eigenvalue. The eigenvector $x$ can be expressed by Equation (2):

$$
A x=\lambda x .
$$

\subsection{Average Degree}

The average network degree $k$ is calculated as the average degree of all hashtags in the network $k i$ divided by the number of hashtags $N$ :

$$
k=\frac{\sum k i}{N}
$$

\subsection{Modularity}

Most complex networks contain nodes that are mutually interconnected to a larger extent than with the rest of the network. Groups of such nodes are called communities [52]. The modularity 
represents an index that identifies the cohesion of communities within a given network [53]. The idea is to identify node communities that are mutually interconnected to a greater degree than other nodes. Networks with a high modularity show strong links between nodes inside modules but weaker links between nodes in different modules [54]. The component analysis then identifies the number of different components (in the case of community modularity) in the network based on the modularity detection analysis [55], as follows:

$$
\Delta \mathrm{Q}=\left[\frac{\sum_{i n}+2 k_{i, i n}}{2 m}-\left(\frac{\sum_{t o t}+k_{i}}{2 m}\right)^{2}\right]-\left[\frac{\sum_{i n}}{2 m}-\left(\frac{\sum_{t o t}}{2 m}\right)^{2}\right],
$$

where $\sum_{i n}$ is the sum of the weighted links inside the community, $\sum_{\text {tot }}$ is the sum of the weighted links incident to the hashtags in the community, $k_{i}$ is the sum of the weighted links incident to the hashtag $i, k_{i, i n}$ is the sum of the weighted links going from $i$ to the hashtags in the community, and $m$ is the normalizing factor as the sum of the weighted links for the whole graph.

\section{Results and Discussion}

The unreduced network contained 44,219 hashtags (nodes) that were interconnected by 423,276 edges. The network was used to identify the frequency and degree values (see Table 2).

A total of 1027 communities were extracted in the unreduced network based on community identification. The reason for a large number of communities lies in the large number of hashtags that contained local hashtags and hashtags created by the users themselves. The network reduction (i.e., removing hashtags that occurred fewer than 50 times in the whole dataset) led to a total of 1927 hashtags. The unreduced network was used for the identification of communities and to calculate the eigenvector centrality value (see Table 2). The reduced network was used for relation analysis (see Tables 3 and 4) and for community analysis (see Table 5).

Table 2. The 40 most frequently used hashtags related to sustainability on Twitter.

\begin{tabular}{cccccccc}
\hline Hashtag & $\mathbf{F}^{*}$ & $\mathbf{C} *$ & EVC ** & Hashtag & $\mathbf{F}^{*}$ & $\mathbf{C} * *$ & EVC ** \\
\hline \#sustainability & 414,926 & 3 & 1.0000 & \#recycling & 6628 & 3 & 0.5013 \\
\#innovation & 32,264 & 5 & 0.7681 & \#energyefficiency & 6316 & 0 & 0.4666 \\
\#environment & 27,054 & 3 & 0.8556 & \#esg & 6104 & 1 & 0.3550 \\
\#climatechange & 23,192 & 4 & 0.7795 & \#leadership & 6054 & 1 & 0.4970 \\
\#tech & 17,746 & 4 & 0.5348 & \#technology & 6012 & 5 & 0.6240 \\
\#csr & 13,608 & 1 & 0.5668 & \#architecture & 5888 & 0 & 0.4185 \\
\#energy & 12,866 & 5 & 0.6999 & \#food & 5808 & 2 & 0.5493 \\
\#renewables & 12,282 & 4 & 0.5339 & \#zerowaste & 5774 & 3 & 0.4671 \\
\#sdgs & 11,644 & 1 & 0.5805 & \#cleanenergy & 5400 & 4 & 0.4654 \\
\#green & 10,836 & 0 & 0.6900 & \#globalgoals & 5386 & 1 & 0.4736 \\
\#sustainable & 10,332 & 3 & 0.7661 & \#plastic & 5332 & 3 & 0.3984 \\
\#earthday & 9814 & 3 & 0.5651 & \#business & 5326 & 1 & 0.6345 \\
\#renewableenergy & 9482 & 4 & 0.5837 & \#eco & 5162 & 3 & 0.4950 \\
\#design & 8498 & 0 & 0.5349 & \#education & 5060 & 1 & 0.4961 \\
\#solar & 8110 & 4 & 0.5014 & \#climateaction & 5046 & 4 & 0.5172 \\
\#circulareconomy & 8088 & 1 & 0.5235 & \#blockchain & 5038 & 5 & 0.4304 \\
\#sac18 & 7666 & 2 & 0.1673 & \#solarenergy & 5028 & 4 & 0.3794 \\
\#foodinnovation & 7520 & 2 & 0.1808 & \#construction & 4998 & 0 & 0.3397 \\
\#climate & 7304 & 4 & 0.5699 & \#ecofriendly & 4854 & 3 & 0.5231 \\
\#water & 6750 & 4 & 0.5533 & \#plasticfree & 4832 & 3 & 0.3618 \\
\hline
\end{tabular}

Note: F: Frequency; D: Degree; C: Community number; EVC: Eigenvector Centrality. ${ }^{*}$ unreduced network; ${ }^{* *}$ reduced network. Source: Authors' results. 
Table 3. The three most frequently used hashtags related to \#sustainability.

\begin{tabular}{cccccc}
\hline \#Innovation & Edge Weight & \#Environment & Edge Weight & \#Climatechange & Edge Weight \\
\hline \#tech & 12,448 & \#climatechange & 4998 & \#environment & 4998 \\
\#environment & 3434 & \#innovation & 3434 & \#climate & 2848 \\
\#renewables & 2986 & \#green & 2422 & \#renewableenergy & 2360 \\
\#technology & 2130 & \#sustainable & 2406 & \#globalwarming & 2242 \\
\#housing & 1956 & \#climate & 2196 & \#sac18 & 2150 \\
\#renewableenergy & 1902 & \#energy & 1980 & \#sustainable & 2092 \\
\#ai & 1820 & \#tech & 1884 & \#energy & 2086 \\
\#smartcity & 1548 & \#pollution & 1724 & \#foodinnovation & 2056 \\
\#iot & 1452 & \#earthday & 1682 & \#climateaction & 1876 \\
\#plastic & 1444 & \#eco & 1586 & \#renewables & 1740 \\
\#energy & 1428 & \#globalwarming & 1464 & \#sdgs & 1724 \\
\#smartcities & 1416 & \#earthday2018 & 1442 & \#innovation & 1346 \\
\#climatechange & 1346 & \#renewableenergy & 1428 & \#nature & 1330 \\
\#transport & 1326 & \#renewables & 1378 & \#foodtech & 1206 \\
\#construction & 1276 & \#nature & 1246 & \#cleanenergy & 1168 \\
\hline
\end{tabular}

Note: Edge Weight: number of connections between hashtags.

Table 4. The top 4-6 hashtags related to \#sustainability according to the frequency of use.

\begin{tabular}{|c|c|c|c|c|c|}
\hline \#Tech & Edge Weight & \#Csr & Edge Weight & \#Energy & Edge Weight \\
\hline \#innovation & 12,448 & \#esg & 2476 & \#solar & 2098 \\
\hline \#renewables & 3820 & \#green & 1486 & \#climatechange & 2086 \\
\hline \#housing & 2180 & \#sdgs & 1330 & \#environment & 1980 \\
\hline \#environment & 1884 & \#leadership & 1258 & \#renewableenergy & 1874 \\
\hline \#construction & 1826 & \#environment & 1162 & \#renewables & 1616 \\
\hline \#renewableenergy & 1450 & \#climatechange & 1100 & \#renewable & 1454 \\
\hline \#electriccars & 1408 & \#supplychain & 1014 & \#innovation & 1428 \\
\hline \#technology & 1212 & \#susty & 890 & \#energyefficiency & 1090 \\
\hline \#transport & 1182 & \#sustainable & 860 & \#cleantech & 966 \\
\hline \#environmenthttps & 1170 & \#rse & 792 & \#blockchain & 948 \\
\hline \#iot & 1168 & \#socialimpact & 774 & \#tech & 938 \\
\hline \#thursdaythoughts & 1158 & \#climate & 770 & \#green & 924 \\
\hline \#ai & 1140 & \#climateaction & 740 & \#cleanenergy & 866 \\
\hline \#smartcities & 1100 & \#ethics & 642 & \#water & 858 \\
\hline \#pollution & 1030 & \#bizhumanrights & 600 & \#climate & 756 \\
\hline
\end{tabular}

Note: Edge Weight: number of connections between hashtags.

Table 5. Communities extracted from the reduced network.

\begin{tabular}{|c|c|c|c|c|}
\hline $\begin{array}{c}\text { Number of } \\
\text { Communities * }\end{array}$ & $\begin{array}{l}\text { Size of the } \\
\text { Community }\end{array}$ & $\begin{array}{l}\text { Number of } \\
\text { Hashtags in the } \\
\text { Community }\end{array}$ & $\begin{array}{l}\text { Name of the } \\
\text { Community }\end{array}$ & Key Hashtags \\
\hline 3 & $23.66 \%$ & 456 & $\begin{array}{l}\text { Environmental } \\
\text { Sustainability }\end{array}$ & $\begin{array}{l}\text { \#environment; \#sustainable; \#earthday; } \\
\text { \#recycling; \#zerowaste; \#plastic; \#eco; } \\
\text { \#ecofriendly; \#plasticfree }\end{array}$ \\
\hline 1 & $22.83 \%$ & 440 & $\begin{array}{l}\text { Sustainability } \\
\text { Awareness }\end{array}$ & $\begin{array}{c}\text { \#csr; \#sdgs; \#circulareconomy; \#esg; } \\
\text { \#supplychain; \#globalgoals; \#business; } \\
\text { \#education }\end{array}$ \\
\hline 4 & $19.88 \%$ & 383 & $\begin{array}{l}\text { Climate Change } \\
\text { and Renewable } \\
\text { Energy }\end{array}$ & $\begin{array}{c}\text { \#climatechange; \#energy; \#renewables; } \\
\text { \#renewableenergy; \#solar; \#climate; \#water; } \\
\text { \#cleanenergy; \#climateaction; \#solarenergy; } \\
\text { \#windpower }\end{array}$ \\
\hline 5 & $12.56 \%$ & 242 & $\begin{array}{l}\text { Innovative } \\
\text { Technology }\end{array}$ & $\begin{array}{c}\text { \#innovation; \#tech; \#technology; \#blockchain; } \\
\text { \#iot; \#ai; \#smartcity }\end{array}$ \\
\hline 0 & $11.16 \%$ & 215 & Green Architecture & $\begin{array}{l}\text { \#design; \#architecture; \#construction; } \\
\text { \#engineering; \#housing; \#greenbuilding }\end{array}$ \\
\hline 2 & $9.91 \%$ & 191 & Food Sustainability & $\begin{array}{l}\text { \#sac18; \#foodinnovation; \#food; \#foodtech; } \\
\text { \#health; \#agriculture; \#foodwaste; \#agtech }\end{array}$ \\
\hline
\end{tabular}

${ }^{*}$ Linked to hashtags in Table 2.

The basic frequency analysis revealed that the most frequently used hashtag in connection to the hashtag \#sustainability was \#innovation. The field of sustainability uses the term Sustainability-Oriented Innovation (SOI) to refer to a key strategic approach that organizations can 
adopt to contribute to sustainable development [56-59] and which is vital for sustainable consumption and production [60]. The hashtag \#innovation was most commonly linked to the hashtag \#tech, i.e., a hashtag that describes technology; of the 32,264 messages containing the hashtag \#innovation, 12,448 also included \#tech. This represents $38.6 \%$ of messages (see Table 3 ). The next most common links to the hashtag \#innovation were \#environment, \#renewables, and \#technology, and each exceeded 2000 links; these hashtags represent innovative technology in renewable energy sources. Innovation in renewable energy technologies (IRET) comprises a significant aspect that influences the overall progress in renewable energy sources $[61,62]$ and could lead to the quicker adoption of renewable energy [63]. In general, renewable energy is considered to be a key factor in the reduction of greenhouse gas emissions and the main substitute for fossil fuels [64]. Renewable sources increase the sustainability of power engineering, the economy, the environment, and society [65].

The hashtag \#environment was the second most frequently used hashtag related to the hashtag \#sustainability (see Table 2). In connection to the community analysis (see Table 5), the expression "environmental sustainability" emerges. Environmental sustainability has multiple definitions. Sustainability-oriented research [66-68] has defined environmental sustainability as a way to "improve human welfare by protecting the sources of raw materials used for human needs and ensuring that the sinks for human wastes are not exceeded" [69] and "the ability to maintain things or qualities that are valued in the natural and biological environments" [70]. In "The Concept of Environmental Sustainability," Goodland (1995) [69] concentrated on the following four elementary activities that influence the scale of human economy: (1) the use of renewable resources, (2) the use of non-renewable resources, (3) reducing air pollution, and (4) waste assimilation. This concept and these definitions could explain the links of the hashtag \#environment with the hashtags \#pollution, \#renewable, \#renewableenergy, \#nature, and \#innovation via the connection to renewable energy [61-63], \#climate, and \#globalwarming [71].

The hashtag \#climatechange was the third most frequently used hashtag related to the hashtag \#sustainability (see Table 2). In connection to the community analysis (see Table 5), this represents the main hashtag in the Climate Change and Renewable Energy community. The hashtag \#climatechange had the strongest links with the hashtags \#climate, \#renewableenergy, and \#globalwarming; this highlights the influence of renewable energy on climate change and global warming, which describe the long-term increase in the Earth's average surface temperature [72]. The impact of renewable sources on global climate change mitigation has been widely recognized [62,73,74]. Renewable sources are not perfect and have some disadvantages, such as higher investment costs, less reliable technology, and issues with the consistency of the energy supply [75]. Therefore, it is necessary to support innovations in the field [53]. For example, China realizes this need and strongly supports the development of renewable energy [75] in the Energy Development Strategy Action Plan (2014-2020)" [76].

The fourth most frequently used hashtag related to the hashtag \#sustainability was \#tech (see Table 4), which was most frequently connected to the hashtags \#innovation, \#renewables, \#housing, \#environment, and \#construction. The link between technological innovation and renewable energy has already been discussed in the previous paragraphs, where the main importance of linking innovations with renewable sources could be a key factor in reducing greenhouse gas emissions and the main substitute for fossil fuels [54]. In connection with \#tech and \#renewables, the hashtags \#housing and \#construction also represented buildings powered with renewable energy. For example, Norway is building a city that will be completely powered by renewable energy (e.g., the tweets "\#housing \#transport \#Sustainability \#RenewableEnergy \#renewables \#tech \#innovation \#MondayMotivation" or "Australia now has 2 million homes with solar panels. \#SolarEnergy \#renewables \#tech \#innovation \#sustainability \#housing \#construction"). Hashtags in tweets constitute a part of the innovative technology community, along with the hashtags \#innovation, \#technology, \#blockchain, \#iot, \#ai, and \#smartcity (see Table 5). The hashtags \#iot, i.e., the Internet of Things, and \#ai, i.e., Artificial Intelligence, comprise two main components of \#smartcities - Smart Cities [77-79]. 
The hashtag \#CSR represents corporate social responsibility and was the fifth most frequent hashtag (see Table 4). Corporate social responsibility is broadly defined as a "firm's commitment to minimizing potential harmful effects of its operations on its stakeholders (owners, employees, customers, community, and the society at large) and maximizing its long-run beneficial impact on society" [80]. CSR is also important from the employee perspective. The CSR activities of a company have a significant influence on employee engagement [81]; customer behavior in choosing products [82,83]; stakeholders, whereby sustainability-oriented innovation enables firms to reap financial benefits [84]; and company owners, given that taking advantage of CSR activities leads to an increase in profits [85]. The hashtag \#CSR was most strongly linked to the hashtag \#esg, i.e., environmental, social, and governance (ESG). The concept of ESG refers to corporate reporting that focuses on environmental, social, and governance performance [86]. Companies using this concept show a higher performance level and a higher rate of innovation [87]. Overall, this concept encourages the use of beneficial environmental practices, such as taking measures to control pollution and the further investment of companies in improving the environment [88].

The sixth most frequently used hashtag related to the hashtag \#sustainability was \#energy (see Table 4). This hashtag was most strongly connected to the hashtag \#solar, which refers to solar energy as a renewable source. It was also linked to the hashtag \#climatechange, which expresses the relationship whereby renewable energy sources are used as an important way to decrease greenhouse gas emissions [89-92]. The hashtags \#innovation and \#environment, in relation to \#energy, have been discussed in previous paragraphs. The hashtag \#blockchain represents a unique occurrence here, however. Blockchain is a technology that has undergone development in the three following stages [93]: Blockchain 1.0 was mostly used for cryptocurrencies; blockchain 2.0 supported digital protocols that automatically execute predefined transaction processes without intermediaries; and blockchain 3.0 increased its autonomy by means of decentralization based on smart contracts with transaction records on the blockchain. Blockchain 2.0 can be easily used by small renewable energy producers to integrate it into new infrastructures (smart grids), and it helps maintain a balance between the energy supply and demand via the support of peer-to-peer exchange [93-95].

The community analysis extracted six communities (see Table 5). The value of the modularity was very low (0.188), which indicates that the hashtags were interconnected similarly well between communities as they were within a given community. A similar phenomenon has been reported for farmers' markets, with a value of 0.221 [42], and for organic food, with a value of 0.303 [41]. On the contrary, the area of gamification shows traits of a polarized network, with a value of 0.506 [96], which is similar to the field of communication analysis in politics [97].

The community analysis followed a different calculation process (see the Modularity subsection in the Methodology section) from the analysis of the interconnections between the individual hashtags by means of the edge value (Tables 3 and 4). For this reason, the interconnection of the individual hashtags may be different from the analysis based on the value of the edge weight.

\subsection{Communities: Environmental Sustainability and Food Sustainability}

The largest community was the Environmental Sustainability community. This community focuses on the environment, recycling, zero waste, and decreasing plastic use and packaging (potentially using reusable packaging), which represents a branch of so-called waste management [98,99]. This result highlights the important problem of "plastic pollution", where many studies point out that plastic pollution is one major global challenge within environmental sustainability $[100,101]$. Figure 3 shows the links of the community to the Food Sustainability community, and indicates the use of the so-called waste management concept in food production, which supports previous research [102]. Reducing food waste is crucial for the sustainability challenge in the food service industry [103-105]. 


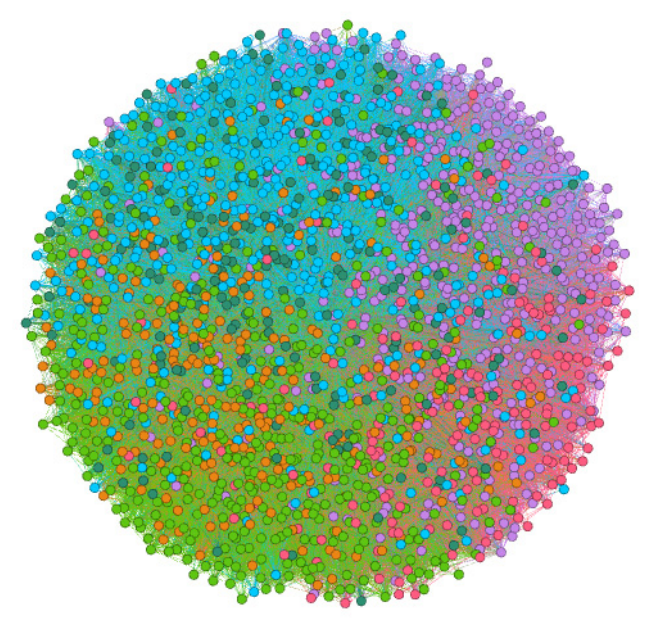

\section{Environmental Sustainability}

Sustainability Awareness

Renewable Energy and Climate Change

Innovative Technology

Green Architecture

Food Sustainability

Figure 3. Communities' polarization on the Twitter social network in the area of sustainability.

\subsection{Communities: Sustainability Awareness and Innovative Technology}

The hashtag \#csr, i.e., Corporate Social Responsibility, represents a key hashtag in the Sustainability Awareness community. In this community, this hashtag co-occurs with the hashtag \#sdgs, i.e., Sustainable Development Goals. In 2015, a document was published, called "Transforming our world: the 2030 Agenda for Sustainable Development" [106]. The publication defined 17 Sustainable Development Goals (see the Introduction section). Another hashtag that occurred was \#esg, referring to the corporate reporting of environmental, social, and governance performance [86]. For Circular Economy (hashtag \#circulareconomy), no unified definition exists [107]. Circular economy is gaining importance for a sustainable future [108] but represents a rather theoretical concept that companies have tried to implement [109] by reducing their consumption of raw materials, designing more eco-friendly products (eco-design), and recovering raw materials from the waste flow [110,111]. The current emphasis is on the so-called supply chain, where CSR comprises a key component for organizations that deliver economic, social, and environmental benefits [112]. All these hashtags (\#csr, \#sdgs, \#esg, \#circulareconomy, and \#supplychain) are linked to business. Companies are urged to integrate this concept into their business [113-115]. This community, shown in Figure 3, is connected to the Innovate Technology community, which focuses on innovation (\#innovation), technology (\#tech), artificial intelligence and the Internet of Things (\#ai and \#iot), blockchain (\#blockchain), and smart cities (\#smartcity). This result is supported by the fact that CSR is an important tool for the communication of values, especially for companies with a focus on innovative technology [116]. The Whole Innovative Technology community concentrates on technologies that support environmental sustainability.

\subsection{Communities: Climate Change and Renewable Energy and Green Architecture}

These communities are focused on the influence of energy and renewable energy on climate change. The impact of renewable sources on climate change by means of decreasing greenhouse gas emissions has been proven [89-92]. These communities mostly connect to the Green Architecture community, as shown in Figure 3. Green architecture, also known as sustainable architecture or green building, refers to the construction of buildings using environmentally friendly principles [117], such as eco-friendly building materials [118], energy-efficient lighting, water-saving plumbing, and alternate power sources such as solar or wind power [119]. This concept helps to harmonize economic growth and environmental protection for sustainable development [120].

Finally, some limitations of our study deserve attention. First of all, like other social network analyses, this study focuses only on one social network [39,40,108,109] and on English keywords. Second, the study analyzes the current situation and does not deal with predictions for the future. In our future research, we will focus on using artificial intelligence to predict trends in social network 
communication. Third, the study analyzed the global data without regional differences. In future studies, it will be possible to analyse these differences (for example, developing countries vs. developed countries; EU vs. Asia; etc.).

Moreover, future research should focus on a proposal of decision-making support, developing a dynamic model for a large-scale communication design and an analytic framework. It will enable sophisticated decisions based on the knowledge of a broad range of factors influencing communications on social media, therefore allowing for more effective campaigns. Moreover, future research will also focus on periodical data collection to analyse the trends in communities. Such long term research will be tightly coupled with an analysis of international sustainability policies, which will lead to the analysis of the influence of these policies on community opinions.

\section{Conclusions}

This work contributes, both methodologically and conceptually, to the knowledge and discussion on sustainability. Our study has proposed new methods to identify current key areas of communication by means of a hashtag analysis on social networks in the area of sustainability. Furthermore, it provides fundamental information about the communication of sustainability in the Twitter social network. This research provides a tool for monitoring and identifying current technological trends, which could be crucial for government policy, research and development, strategic planning, social investment, and enterprise practices, e.g., creating support for an alternative business model for food producers with connections to food sustainability or energy producers, such as solar or wind energy. From companies' point of view, social network analysis is a usable and approachable tool for identifying current trends, such as the use of blockchain as a technology for small energy producers to balance the energy supply from renewable resources.

The communication analysis of posts within the Twitter social network that were related to the hashtag \#sustainability showed that there was a heavy emphasis on innovation, mainly in the area of the environment (\#environment and \#environments), climate change (\#climatechange) and renewable energy sources (\#energy and \#renewableenergy). The frequency and eigenvector centrality value analyses identified other significant hashtags, namely: \#tech in relation to innovation in the field of renewable sources and \#csr (Corporate Social Responsibility), mainly in connection to the hashtag \#esg. The hashtag \# esg refers to corporate reporting that focuses on environmental, social, and governance performance, and, finally, the hashtag \#energy is in relation to climate change and innovation in renewable sources. Nevertheless, these results are not only caused by communication between individuals. The companies in the sector of renewable energy and environmental sustainability perceive the importance of communication with the community, and they are using social networks as an effective channel for a two-way communication with target groups.

The community analyses allowed us to define six key areas that were communicated on the Twitter social network: (1) Environmental Sustainability, (2) Sustainability awareness, (3) Renewable energy and Climate change, (4) Innovative Technology, (5) Green Architecture, and (6) Food Sustainability. The intersection of the results showed that innovations that focus on renewable sources to improve the environment are the main topic on the Twitter social network. The community analysis has also identified important findings regarding a low polarity between communities. There is even a high interdependence of some communities (Environmental Sustainability is interconnected with Food Sustainability; Sustainability Awareness interacts with Innovative Technology; the Climate Change and Renewable Energy community has a significant intersection with Green Architecture), which is important for a comprehensive understanding of all sustainability communication on Twitter.

Social media has become a particularly important platform for discussing sustainability in various contexts. Twitter's pervasiveness makes it a convenient tool for a discussion stimulation that may encourage interactions with savvy consumers who expect to be able to hold a dialogue about the topic. It appears to be the right medium to develop a brand voice, particularly for small- and medium-sized 
businesses (with limited time and resources), and to prepare a strategic communication plan to connect with key stakeholders and the public.

Based on this knowledge, it is possible to identify the following highlights regarding communication on Twitter connected to sustainability:

- The most interconnected topic with sustainability is area of innovation;

- Innovation is linked to technology ( $45 \%$ of all Tweets related to innovation), which is linked the most to the environment ( $26 \%$ of all Tweets related to technology);

- Innovation, in terms of renewable energy, is focused on climate change via the reduction of greenhouse gas emissions;

- CSR, in relation to sustainability, is focused on ESG principles.

Author Contributions: Conceptualization, L.P. and L.K.S.; methodology, L.P.; validation, L.P.; formal analysis, L.P.; L.K.S.; resources, L.K.S.; data curation, L.P.; writing—original draft preparation, L.P. and L.K.S. and J.P. and I.K. and I.T.; writing-review and editing, L.P. and L.K.S. and J.P. and I.K. and I.T. and M.C.; visualization, P.L.; supervision, I.T.; project administration, L.P. and J.P.

Funding: This article was created with the support of the Internal Grant Agency (IGA) of FEM CULS in Prague, registration no. 2019B0006 - Attributes of alternative business models management in Food Production.

Conflicts of Interest: The authors declare no conflict of interest. The funders had no role in the design of the study; in the collection, analyses, or interpretation of data; in the writing of the manuscript, or in the decision to publish the results.

\section{References}

1. Zhou, B.-B.; Wu, J.; Anderies, J.M. Sustainable landscapes and landscape sustainability: A tale of two concepts. Landsc. Urban Plan. 2019, 189, 274-284. [CrossRef]

2. Mora, P. Wine Business Case Studies: Thirteen Cases from the Real World of Wine Business Management; Board and Bench Publishing: San Francisco, CA, USA, 2014; ISBN 978-1935879718.

3. Steffen, W.; Noone, K.; Lambin, E.; Lenton, T.M.; Scheffer, M.; Folke, C.; Schellnhuber, H.J.; De Wit, C.A.; Hughes, T.; Van Der Leeuw, S.; et al. Planetary Boundaries: Exploring the Safe Operating Space for Humanity. Ecol. Soc. 2009, 14, 32.

4. Egrenfeld, J.R. The roots of sustainability. Sloan Manag. Rev. 2010, 26, 23-25.

5. Drexhage, J.; Murphy, D. Sustainable Development: From Brundtland to Rio 2012; United Nations Working Paper; United Nations Headquarters: New York, NY, USA, 2010; pp. 1-26.

6. Sachs, J.; McArthur, J. The Millennium Project: A plan for meeting the Millennium Development Goals. Lancet 2005, 365, 347-353. [CrossRef]

7. Robert, K.W.; Parris, T.M.; Leiserowitz, A.A. What is Sustainable Development? Goals, Indicators, Values, and Practice. Environ. Sci. Policy Sustain. Dev. 2005, 47, 8-21. [CrossRef]

8. Burton, I. Report on Reports: Our Common Future. Environ. Sci. Policy Sustain. Dev. 1987, 29, 25-29. [CrossRef]

9. Zhiznin, S.Z.; Vassilev, S.; Gusev, A.L. Economics of secondary renewable energy sources with hydrogen generation. Int. J. Hydrogen Energy 2019, 44, 11385-11393. [CrossRef]

10. Van Schoubroeck, S.; Springael, J.; Van Dael, M.; Malina, R.; Van Passel, S. Sustainability indicators for biobased chemicals: A Delphi study using Multi-Criteria Decision Analysis. Resour. Conserv. Recycl. 2019, 144, 198-208. [CrossRef]

11. Oubraham, A.; Zaccour, G. A Survey of Applications of Viability Theory to the Sustainable Exploitation of Renewable Resources. Ecol. Econ. 2018, 145, 346-367. [CrossRef]

12. Krajačić, G.; Vujanović, M.; Duić, N.; Kılkıs, Ş.; Rosen, M.A.; Ahmad Al-Nimr, M. Integrated approach for sustainable development of energy, water and environment systems. Energy Convers. Manag. 2018, 159, 398-412. [CrossRef]

13. Okokpujie, I.P.; Fayomi, O.S.I.; Oyedepo, S.O. The Role of Mechanical Engineers in Achieving Sustainable Development Goals. Procedia Manuf. 2019, 35, 782-788. [CrossRef]

14. Roinioti, A.; Koroneos, C. Integrated life cycle sustainability assessment of the Greek interconnected electricity system. Sustain. Energy Technol. Assess. 2019, 32, 29-46. [CrossRef] 
15. Turetta, A.P.D.; Kuyper, T.; Malheiros, T.F.; da Costa Coutinho, H.L. Corrigendum to “A framework proposal for sustainability assessment of sugarcane in Brazil" [Land Use Policy 68 (2017) 597-603]. Land Use Policy 2017, 72, 578-585. [CrossRef]

16. Albert, M. Sustainable frugal innovation-The connection between frugal innovation and sustainability. J. Clean. Prod. 2019, 237, 117747. [CrossRef]

17. Wang, Y.-Z.; Lo, F.-Y.; Weng, S.-M. Family businesses successors knowledge and willingness on sustainable innovation: The moderating role of leader's approval. J. Innov. Knowl. 2019, 4, 188-195. [CrossRef]

18. Martins, V.W.B.; Rampasso, I.S.; Anholon, R.; Quelhas, O.L.G.; Leal Filho, W. Knowledge management in the context of sustainability: Literature review and opportunities for future research. J. Clean. Prod. 2019, 229, 489-500. [CrossRef]

19. Goti-Aralucea, L.; Fitzpatrick, M.; Döring, R.; Reid, D.; Mumford, J.; Rindorf, A. Overarching sustainability objectives overcome incompatible directions in the Common Fisheries Policy. Mar. Policy 2018, 91, 49-57. [CrossRef]

20. Wiener, M.; Gattringer, R.; Strehl, F. Collaborative open foresight-A new approach for inspiring discontinuous and sustainability-oriented innovations. Technol. Forecast. Soc. Chang. 2018, 119370. [CrossRef]

21. Asr, E.T.; Kakaie, R.; Ataei, M.; Tavakoli Mohammadi, M.R. A review of studies on sustainable development in mining life cycle. J. Clean. Prod. 2019, 229, 213-231. [CrossRef]

22. Aznar-Sánchez, J.A.; Belmonte-Ureña, L.J.; Velasco-Muñoz, J.F.; Manzano-Agugliaro, F. Economic analysis of sustainable water use: A review of worldwide research. J. Clean. Prod. 2018, 198, 1120-1132. [CrossRef]

23. Antonson, H.; Levin, L. A crack in the Swedish welfare façade? A review of assessing social impacts in transport infrastructure planning. Prog. Plan. 2018. [CrossRef]

24. Park, Y.S.; Lim, S.H.; Egilmez, G.; Szmerekovsky, J. Environmental efficiency assessment of U.S. transport sector: A slack-based data envelopment analysis approach. Transp. Res. Part D Transp. Environ. 2018, 61, 152-164. [CrossRef]

25. Cracolici, M.F.; Cuffaro, M.; Lacagnina, V. Assessment of Sustainable Well-being in the Italian Regions: An Activity Analysis Model. Ecol. Econ. 2018, 143, 105-110. [CrossRef]

26. Henckens, M.L.C.M.; Ryngaert, C.M.J.; Driessen, P.P.J.; Worrell, E. Normative principles and the sustainable use of geologically scarce mineral resources. Resour. Policy 2018, 59, 351-359. [CrossRef]

27. Matthews, N.E.; Stamford, L.; Shapira, P. Aligning sustainability assessment with responsible research and innovation: Towards a framework for Constructive Sustainability Assessment. Sustain. Prod. Consum. 2019, 20, 58-73. [CrossRef]

28. Kenney-Lazar, M.; Wong, G.; Baral, H.; Russell, A.J.M. Greening rubber? Political ecologies of plantation sustainability in Laos and Myanmar. Geoforum 2018, 92, 96-105. [CrossRef]

29. Rantala, T.; Ukko, J.; Saunila, M.; Havukainen, J. The effect of sustainability in the adoption of technological, service, and business model innovations. J. Clean. Prod. 2018, 172, 46-55. [CrossRef]

30. Joglekar, S.N.; Kharkar, R.A.; Mandavgane, S.A.; Kulkarni, B.D. Sustainability assessment of brick work for low-cost housing: A comparison between waste based bricks and burnt clay bricks. Sustain. Cities Soc. 2018, 37, 396-406. [CrossRef]

31. Elkington, J. Cannibals With Forks: Triple Bottom Line of 21st Century Business; John Wiley \& Son Ltd.: Hoboken, NJ, USA, 1997; ISBN 1841120847,978-1841120843.

32. Kostoska, O.; Kocarev, L. A Novel ICT Framework for Sustainable Development Goals. Sustainability 2019, 11, 1961. [CrossRef]

33. Biermann, F.; Kanie, N.; Kim, R.E. Global governance by goal-setting: the novel approach of the UN Sustainable Development Goals. Curr. Opin. Environ. Sustain. 2017, 26-27, 26-31. [CrossRef]

34. Li, X.; Xie, Q.; Jiang, J.; Zhou, Y.; Huang, L. Identifying and monitoring the development trends of emerging technologies using patent analysis and Twitter data mining: The case of perovskite solar cell technology. Technol. Forecast. Soc. Chang. 2019, 146, 687-705. [CrossRef]

35. Yoon, J.; Park, H.; Seo, W.; Lee, J.-M.; Coh, B.; Kim, J. Technology opportunity discovery (TOD) from existing technologies and products: A function-based TOD framework. Technol. Forecast. Soc. Chang. 2015, 100, 153-167. [CrossRef]

36. Clement, J. Number of Social Network Users Worldwide from 2010 to 2021 (in billions). Available online: https://www.statista.com/statistics/278414/number-of-worldwide-social-network-users (accessed on 6 October 2019). 
37. Malthouse, E.C.; Haenlein, M.; Skiera, B.; Wege, E.; Zhang, M. Managing customer relationships in the social media era: Introducing the social CRM house. J. Interact. Mark. 2013, 27, 270-280. [CrossRef]

38. Loures, T.C.; de Melo, P.O.S.V.; Veloso, A.A. Is it possible to describe television series from online comments? J. Internet Serv. Appl. 2018, 9, 25. [CrossRef]

39. Gaur, A.; Kumar, M. A systematic approach to conducting review studies: An assessment of content analysis in 25 years of IB research. J. World Bus. 2018, 53, 280-289. [CrossRef]

40. Wright, A. Mining the Web for Feelings, Not Facts. Available online: https://www.cnet.com/news/miningthe-web-for-feelings-not-facts (accessed on 6 October 2019).

41. Pilař, L.; Kvasničková Stanislavská, L.; Poláková, J.; Rojík, S.; Kvasnička, R.; Gresham, G. Customer Experience with Organic Food: Global View. Emirates J. Food Agric. 2018, 30. [CrossRef]

42. Pilař, L.; Balcarová, T.; Rojík, S.; Tichá, I.; Poláková, J. Customer experience with farmers' markets: what hashtags can reveal. Int. Food Agribus. Manag. Rev. 2018, 21, 755-770. [CrossRef]

43. Walsh, P.; Clavio, G.; Lovell, M.D.; Blaszka, M. Differences in event brand personality between social media users and non-usersNo Title. Sport Mark. Q. 2013, 22, 214-223.

44. Can, U.; Alatas, B. A new direction in social network analysis: Online social network analysis problems and applications. Phys. A Stat. Mech. Its Appl. 2019, 535, 122372. [CrossRef]

45. Dimitriou, L.; Antoniou, C. Monitoring social network formation and information content analysis of transport anomalies: The case of airline crashes. J. Air Transp. Manag. 2017, 65, 127-141. [CrossRef]

46. Celardo, L.; Everett, M.G. Network text analysis: A two-way classification approach. Int. J. Inf. Manag. 2019. [CrossRef]

47. Park, E. The role of satisfaction on customer reuse to airline services: An application of Big Data approaches. J. Retail. Consum. Serv. 2019, 47, 370-374. [CrossRef]

48. Kumar, A.; Srinivasan, K.; Cheng, W.-H.; Zomaya, A.Y. Hybrid context enriched deep learning model for fine-grained sentiment analysis in textual and visual semiotic modality social data. Inf. Process. Manag. 2020, 57, 102141. [CrossRef]

49. Poell, T. Social media and the transformation of activist communication: exploring the social media ecology of the 2010 Toronto G20 protests. Inf. Commun. Soc. 2014, 17, 716-731. [CrossRef]

50. Gruz, A. Software for Automated Text and Social Network Analysis. Available online: http://Netlytic.org (accessed on 6 October 2019).

51. Fayyad, U.; Piatetsky-Shapiro, G.; Smyth, P. From data mining to knowledge discovery in databases. AI Mag. 1996, 17, 37-54.

52. McCurdie, T.; Sanderson, P.; Aitken, L.M. Applying social network analysis to the examination of interruptions in healthcare. Appl. Ergon. 2018, 67, 50-60. [CrossRef]

53. Newman, M.E.J.; Girvan, M. Finding and evaluating community structure in networks. Phys. Rev. E 2004, 69, 026113. [CrossRef]

54. Knoke, D.; Yang, S. Social Network Analysis; Sage Publications: Thousand Oaks, CA, USA, 2008; Volume 154, ISBN 9781412927499.

55. Blondel, V.D.; Guillaume, J.-L.; Lambiotte, R.; Lefebvre, E. Fast unfolding of communities in large networks. J. Stat. Mech. Theory Exp. 2008, 2008, P10008. [CrossRef]

56. Inigo, E.A.; Albareda, L. Sustainability oriented innovation dynamics: Levels of dynamic capabilities and their path-dependent and self-reinforcing logics. Technol. Forecast. Soc. Chang. 2019, 139, 334-351. [CrossRef]

57. Fichter, K.; Clausen, J. Diffusion Dynamics of Sustainable Innovation-Insights on Diffusion Patterns Based on the Analysis of 100 Sustainable Product and Service Innovations. J. Innov. Manag. 2016, 4, 30-67. [CrossRef]

58. Hansen, E.G.; Grosse-Dunker, F. Sustainability-Oriented Innovation. In Encyclopedia of Corporate Social Responsibility; Idowu, S.O., Capaldi, N., Zu, L., Das Gupta, A., Eds.; Springer: Berlin/Heidelberg, Germany, 2013; pp. 2407-2417. ISBN 978-3-642-28035-1.

59. Watson, R.; Wilson, H.N.; Macdonald, E.K. Business-nonprofit engagement in sustainability-oriented innovation: What works for whom and why? J. Bus. Res. 2018. [CrossRef]

60. Buhl, A.; Schmidt-Keilich, M.; Muster, V.; Blazejewski, S.; Schrader, U.; Harrach, C.; Schäfer, M.; Süßbauer, E. Design thinking for sustainability: Why and how design thinking can foster sustainability-oriented innovation development. J. Clean. Prod. 2019, 231, 1248-1257. [CrossRef] 
61. Lin, B.; Zhu, J. Determinants of renewable energy technological innovation in China under CO2 emissions constraint. J. Environ. Manag. 2019, 247, 662-671. [CrossRef] [PubMed]

62. Lin, B.; Chen, Y. Does electricity price matter for innovation in renewable energy technologies in China? Energy Econ. 2019, 78, 259-266. [CrossRef]

63. Chen, W.; Lei, Y. The impacts of renewable energy and technological innovation on environment-energy-growth nexus: New evidence from a panel quantile regression. Renew. Energy 2018, 123, 1-14. [CrossRef]

64. Kuriqi, A.; Pinheiro, A.N.; Sordo-Ward, A.; Garrote, L. Influence of hydrologically based environmental flow methods on flow alteration and energy production in a run-of-river hydropower plant. J. Clean. Prod. 2019, 232, 1028-1042. [CrossRef]

65. Wang, Q.; Zhan, L. Assessing the sustainability of renewable energy: An empirical analysis of selected 18 European countries. Sci. Total Environ. 2019, 692, 529-545. [CrossRef]

66. Aşıc1, A.A. Economic growth and its impact on environment: A panel data analysis. Ecol. Indic. 2013, 24, 324-333. [CrossRef]

67. Moldan, B.; Janoušková, S.; Hák, T. How to understand and measure environmental sustainability: Indicators and targets. Ecol. Indic. 2012, 17, 4-13. [CrossRef]

68. Bjørn, A.; Margni, M.; Roy, P.-O.; Bulle, C.; Hauschild, M.Z. A proposal to measure absolute environmental sustainability in life cycle assessment. Ecol. Indic. 2016, 63, 1-13. [CrossRef]

69. Goodland, R. The Concept of Environmental Sustainability. Annu. Rev. Ecol. Syst. 1995, 26, 1-24. [CrossRef]

70. Sutton, P. A Perspective on Environmental Sustainability? Strategy of Green Innovations; RSTI Publications, Inc.: Melbourne, Austria, 2004.

71. Jang, S.M.; Hart, P.S. Polarized frames on "climate change" and "global warming" across countries and states: Evidence from Twitter big data. Glob. Environ. Chang. 2015, 32, 11-17. [CrossRef]

72. Emodi, N.V.; Chaiechi, T.; Beg, A.B.M.R.A. The impact of climate variability and change on the energy system: A systematic scoping review. Sci. Total Environ. 2019, 676, 545-563. [CrossRef] [PubMed]

73. Wang, D.D.; Sueyoshi, T. Climate change mitigation targets set by global firms: Overview and implications for renewable energy. Renew. Sustain. Energy Rev. 2018, 94, 386-398. [CrossRef]

74. Wang, B.; Wang, Q.; Wei, Y.-M.; Li, Z.-P. Role of renewable energy in China's energy security and climate change mitigation: An index decomposition analysis. Renew. Sustain. Energy Rev. 2018, 90, 187-194. [CrossRef]

75. Li, J.; Kong, C.; Duan, Q.; Luo, T.; Mei, Z.; Lei, Y. Mass flow and energy balance plus economic analysis of a full-scale biogas plant in the rice-wine-pig system. Bioresour. Technol. 2015, 193, 62-67. [CrossRef]

76. National Energy Administration Strategic Plan for Energy Development. Available online: http://www.nea.gov.cn/2014-12/03/c_133830458.htm?fbclid= IwAR2egAArqPvMjPG1O0LAC7xxKWsTFLP8ILQX90Jp9FAYU-ojqh93tTeMFSQ (accessed on 12 October 2019).

77. Sanchez, L.; Muñoz, L.; Galache, J.A.; Sotres, P.; Santana, J.R.; Gutierrez, V.; Ramdhany, R.; Gluhak, A.; Krco, S.; Theodoridis, E.; et al. SmartSantander: IoT experimentation over a smart city testbed. Comput. Netw. 2014, 61, 217-238. [CrossRef]

78. Albino, V.; Berardi, U.; Dangelico, R.M. Smart Cities: Definitions, Dimensions, Performance, and Initiatives. J. Urban Technol. 2015, 22, 3-21. [CrossRef]

79. Gazzola, P.; Del Campo, A.G.; Onyango, V. Going green vs going smart for sustainable development: Quo vadis? J. Clean. Prod. 2019, 214, 881-892. [CrossRef]

80. Hegde, S.P.; Mishra, D.R. Married CEOs and corporate social responsibility. J. Corp. Financ. 2019, 58, $226-246$. [CrossRef]

81. Duthler, G.; Dhanesh, G.S. The role of corporate social responsibility (CSR) and internal CSR communication in predicting employee engagement: Perspectives from the United Arab Emirates (UAE). Public Relat. Rev. 2018, 44, 453-462. [CrossRef]

82. Li, Y.; Fu, H.; Huang, S. (Sam) Does conspicuous decoration style influence customer's intention to purchase? The moderating effect of CSR practices. Int. J. Hosp. Manag. 2015, 51, 19-29. [CrossRef]

83. Fatma, M.; Rahman, Z. The CSR's influence on customer responses in Indian banking sector. J. Retail. Consum. Serv. 2016, 29, 49-57. [CrossRef] 
84. Ghassim, B.; Bogers, M. Linking stakeholder engagement to profitability through sustainability-oriented innovation: A quantitative study of the minerals industry. J. Clean. Prod. 2019, 224, 905-919. [CrossRef]

85. Abaeian, V.; Yeoh, K.K.; Khong, K.W. An Exploration of CSR Initiatives Undertaken by Malaysian Hotels: Underlying Motivations from a Managerial Perspective. Procedia Soc. Behav. Sci. 2014, 144, 423-432. [CrossRef]

86. Husted, B.W.; de Sousa-Filho, J.M. Board structure and environmental, social, and governance disclosure in Latin America. J. Bus. Res. 2019, 102, 220-227. [CrossRef]

87. Broadstock, D.C.; Matousek, R.; Meyer, M.; Tzeremes, N.G. Does corporate social responsibility impact firms' innovation capacity? The indirect link between environmental \& social governance implementation and innovation performance. J. Bus. Res. 2019. [CrossRef]

88. Husted, B.W.; de Sousa-Filho, J.M. The impact of sustainability governance, country stakeholder orientation, and country risk on environmental, social, and governance performance. J. Clean. Prod. 2017, 155, 93-102. [CrossRef]

89. Jenniches, S. Assessing the regional economic impacts of renewable energy sources-A literature review. Renew. Sustain. Energy Rev. 2018, 93, 35-51. [CrossRef]

90. Liobikienè, G.; Butkus, M. The challenges and opportunities of climate change policy under different stages of economic development. Sci. Total Environ. 2018, 642, 999-1007. [CrossRef]

91. Azhgaliyeva, D. Energy Storage and Renewable Energy Deployment: Empirical Evidence from OECD countries. Energy Procedia 2019, 158, 3647-3651. [CrossRef]

92. Bhattacharya, M.; Awaworyi Churchill, S.; Paramati, S.R. The dynamic impact of renewable energy and institutions on economic output and $\mathrm{CO}_{2}$ emissions across regions. Renew. Energy 2017, 111, 157-167. [CrossRef]

93. Brilliantova, V.; Thurner, T.W. Blockchain and the future of energy. Technol. Soc. 2019, 57, 38-45. [CrossRef]

94. Li, Y.; Yang, W.; He, P.; Chen, C.; Wang, X. Design and management of a distributed hybrid energy system through smart contract and blockchain. Appl. Energy 2019, 248, 390-405. [CrossRef]

95. Ahl, A.; Yarime, M.; Tanaka, K.; Sagawa, D. Review of blockchain-based distributed energy: Implications for institutional development. Renew. Sustain. Energy Rev. 2019, 107, 200-211. [CrossRef]

96. Pilar, L.; Moulis, P.; Pitrová, J.; Bouda, P.; Gresham, G.; Balcarová, T.; Rojík, S. Education and Business as a key topics at the Instagram posts in the area of Gamification. J. Effic. Responsib. Educ. Sci. 2019, 12, $26-33$. [CrossRef]

97. Weaver, I.S.; Williams, H.; Cioroianu, I.; Jasney, L.; Coan, T.; Banducci, S. Communities of online news exposure during the UK General Election 2015. Online Soc. Netw. Media 2019, 10-11, 18-30. [CrossRef]

98. Geueke, B.; Groh, K.; Muncke, J. Food packaging in the circular economy: Overview of chemical safety aspects for commonly used materials. J. Clean. Prod. 2018, 193, 491-505. [CrossRef]

99. Beitzen-Heineke, E.F.; Balta-Ozkan, N.; Reefke, H. The prospects of zero-packaging grocery stores to improve the social and environmental impacts of the food supply chain. J. Clean. Prod. 2017, 140, 1528-1541. [CrossRef]

100. Heidbreder, L.M.; Bablok, I.; Drews, S.; Menzel, C. Tackling the plastic problem: A review on perceptions, behaviors, and interventions. Sci. Total Environ. 2019, 668, 1077-1093. [CrossRef]

101. Tessnow-von Wysocki, I.; Le Billon, P. Plastics at sea: Treaty design for a global solution to marine plastic pollution. Environ. Sci. Policy 2019, 100, 94-104. [CrossRef]

102. Thamagasorn, M.; Pharino, C. An analysis of food waste from a flight catering business for sustainable food waste management: A case study of halal food production process. J. Clean. Prod. 2019, 228, 845-855. [CrossRef]

103. Martin-Rios, C.; Demen-Meier, C.; Gössling, S.; Cornuz, C. Food waste management innovations in the foodservice industry. Waste Manag. 2018, 79, 196-206. [CrossRef] [PubMed]

104. Garcia-Garcia, G.; Woolley, E.; Rahimifard, S. Optimising Industrial Food Waste Management. Procedia Manuf. 2017, 8, 432-439. [CrossRef]

105. Filimonau, V.; De Coteau, D.A. Food waste management in hospitality operations: A critical review. Tour. Manag. 2019, 71, 234-245. [CrossRef]

106. UN-United Nation. Transforming Our World: The 2030 Agenda for Sustainable Development; United Nations: New York, NY, USA, 2015. 
107. Moraga, G.; Huysveld, S.; Mathieux, F.; Blengini, G.A.; Alaerts, L.; Van Acker, K.; de Meester, S.; Dewulf, J. Circular economy indicators: What do they measure? Resour. Conserv. Recycl. 2019, 146, 452-461. [CrossRef] [PubMed]

108. Hanumante, N.C.; Shastri, Y.; Hoadley, A. Assessment of circular economy for global sustainability using an integrated model. Resour. Conserv. Recycl. 2019, 151, 104460. [CrossRef]

109. Govindan, K.; Hasanagic, M. A systematic review on drivers, barriers, and practices towards circular economy: a supply chain perspective. Int. J. Prod. Res. 2018, 56, 278-311. [CrossRef]

110. Kirchherr, J.; Piscicelli, L. Towards an Education for the Circular Economy (ECE): Five Teaching Principles and a Case Study. Resour. Conserv. Recycl. 2019, 150, 104406. [CrossRef]

111. Van Buren, N.; Demmers, M.; van der Heijden, R.; Witlox, F. Towards a Circular Economy: The Role of Dutch Logistics Industries and Governments. Sustainability 2016, 8, 647. [CrossRef]

112. Manavalan, E.; Jayakrishna, K. An Analysis on Sustainable Supply Chain for Circular Economy. Procedia Manuf. 2019, 33, 477-484. [CrossRef]

113. Stewart, R.; Niero, M.; Murdock, K.; Olsen, S.I. Exploring the Implementation of a Circular Economy Strategy: The Case of a Closed-loop Supply of Aluminum Beverage Cans. Procedia CIRP 2018, 69, 810-815. [CrossRef]

114. Maqbool, S.; Zameer, M.N. Corporate social responsibility and financial performance: An empirical analysis of Indian banks. Future Bus. J. 2018, 4, 84-93. [CrossRef]

115. Doni, F.; Corvino, A.; Bianchi Martini, S. Servitization and sustainability actions. Evidence from European manufacturing companies. J. Environ. Manag. 2019, 234, 367-378. [CrossRef] [PubMed]

116. Bocquet, R.; Le Bas, C.; Mothe, C.; Poussing, N. Strategic CSR for innovation in SMEs: Does diversity matter? Long Range Plan. 2019, 52, 101913. [CrossRef]

117. Ragheb, A.; El-Shimy, H.; Ragheb, G. Green Architecture: A Concept of Sustainability. Procedia Soc. Behav. Sci. 2016, 216, 778-787. [CrossRef]

118. Bakhoum, E.S.; Garas, G.L.; Allam, M.E. Sustainability analysis of conventional and eco-friendly materials: A step towards green building. ARPN J. Eng. Appl. Sci. 2015, 10, 788-796.

119. Tasci, B.G. "Sustainability" Education by Sustainable School Design. Procedia Soc. Behav. Sci. 2015, 186, 868-873. [CrossRef]

120. Vyas, G.S.; Jha, K.N. Benchmarking green building attributes to achieve cost effectiveness using a data envelopment analysis. Sustain. Cities Soc. 2017, 28, 127-134. [CrossRef]

(C) 2019 by the authors. Licensee MDPI, Basel, Switzerland. This article is an open access article distributed under the terms and conditions of the Creative Commons Attribution (CC BY) license (http://creativecommons.org/licenses/by/4.0/). 